\title{
CHEMICAL COMPOSITIONS AND BIOLOGICAL ACTIVITIES ESSENTIAL OIL FROM THE NEEDLES OF NORTH AFRICAN PINUS PINASTER VAR.
}

\author{
Sondes FKIRI, ${ }^{\mathrm{a}}$ Hanene GHAZGHAZI, ${ }^{\mathrm{a}}$ Ghayth RIGANE, ${ }^{\mathrm{b}, \mathrm{c}^{*}}$ Ridha BEN SALEM,,${ }^{\mathrm{b}}$ Faten MEZNI, ${ }^{\mathrm{a}}$ \\ Abdelhamid KHALDI, ${ }^{\mathrm{a}}$ M. Larbi KHOUJA ${ }^{\mathrm{d}}$ and Zouhair NASR ${ }^{\mathrm{a}}$ \\ ${ }^{a}$ Laboratory of Management and Valorization of Forest Resources, National Research Institute of Rural Engineering, \\ Water and Forestry, B.P 10, 2080 Ariana, Tunisia \\ ${ }^{\mathrm{b}}$ Laboratory of Organic chemistry, LR17ES08, Faculty of Sciences of Sfax, University of Sfax, B.P 1171, 3038 Sfax, Tunisia \\ ${ }^{\mathrm{c}}$ Department of Physics \& Chemistry, Faculty of Sciences and Technology of Sidi Bouzid, B. P 380, 9100, Sidi Bouzid, \\ University of Kairouan, Tunisia \\ ${ }^{\mathrm{d}}$ Laboratory of Forest ecology, National Research Institute of Rural Engineering, Water and Forestry, B.P 10, 2080 Ariana, Tunisia
}

The essential oil from needles of Pinus pinaster two varieties, obtained by hydrodistillation, was analysed by GC-MS and GC-FID. Sesquiterpenes represented the main fraction. The major components of Renoui variety essential oil were trans-caryophyllene (14.66\%), abietane $(8.61 \%)$, $\Delta$-cadinene $(8.43 \%)$ and sclarene $(8.25 \%)$, while, $\alpha$ amorphene $(10.72 \%)$, followed by trans-caryophyllene $(10.74 \%)$, $\beta$-cadinene $(9.73 \%)$ were the major constituents found in the essential oil from Maghrebiana variety. The highest antibacterial activity was found against $S$. aureus and B. cereus. Based on the two DPPH and ABTS tests, the investigated oils highlighted important in vitro antioxidant capacities.

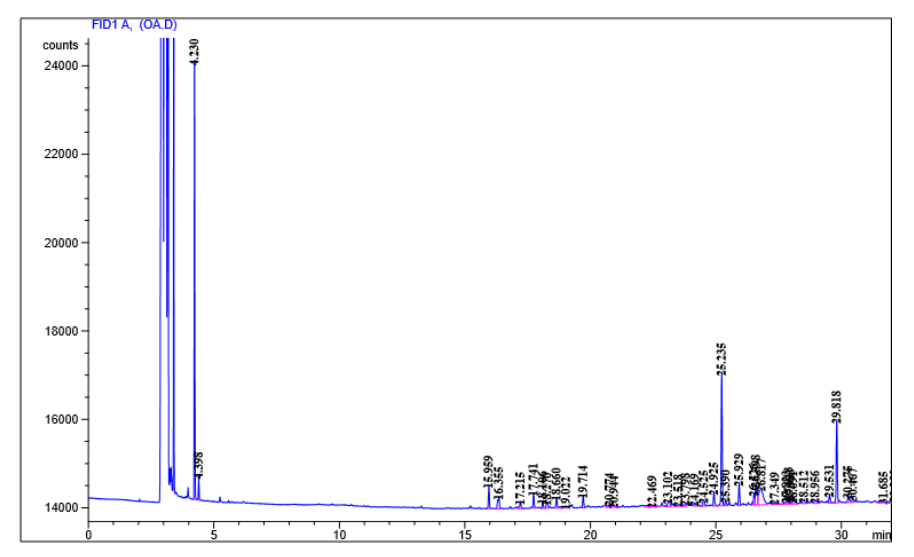

\section{INTRODUCTION}

Essential oils and their components are very demanded by consumers; therefore, they have an interest in the food and pharmaceutical industries as natural antioxidants. ${ }^{1}$ Pine oils are widely used as fragrances, flavoring, intermediates in the synthesis and beverages. Traditional therapeutic and pharmaceutical uses of its oils are recorded all around the world. ${ }^{2}$ Pine needles essential oils are mainly used in folk medicine for the treatment of cardiovascular and cholesterol lowering benefits, respiratory infection, they have a powerful antioxidant and anti-inflammatory effects and the ability to enhance microcirculation by increasing capillary permeability. ${ }^{3}$ Maritime pine (Pinus pinaster Aiton) was broadly distributed under Mediterranean climates of Europe, such as Portugal, Spain and Italy, as well as in some north western African countries such as Maroco and Tunisia. ${ }^{4}$ In Tunisia, this species represented $68 \%$ of the national forests areas $^{5}$, the Renoui variety is native to the humid and sub-humid areas, mainly in the regions of Tabarka and Ain Drahem. In Morocco, Maghrebiana variety of Pinus pinaster, spontaneous in the humid and sub-humid bio climate, represents approximately $90 \%$ of the coniferous plantations of Rif and the oriental Middle Atlas. ${ }^{6}$ Several studies have been carried out on composition of Pinus pinaster essential oils mentioned that these oils

\footnotetext{
* Corresponding author: gaith.rigane@yahoo.fr
} 
were dominated by monoterpene and sesquiterpene hydrocarbons or a combination of both them.

Instead, to our knowledge, this comparison of the essential oils of two varieties of Pinus pinaster from two different origin from North African area planted in experimental site of Souiniet (Tunisia: Ain Drahem) have never been described. Therefore, the objective of this study was to determine the phytochemistry of $P$. pinaster varieties endemic from North Africa as well as it biological activities.

\section{MATERIALS AND METHODS}

\section{Plant material}

Needles of Pinus pinaster of two varieties, the first one was from Tunisia (var. Renoui) while the second were from Marocco (var. Maghrebiana), were collected in May 2014 from Souiniet arboretum in Northwest of Tunisia ( $8^{\circ} 48$ E, $\left.35^{\circ} 54 \mathrm{~N}, 492 \mathrm{~m}\right)$. The cultivated region is characterized by an annual temperature $15.6{ }^{\circ} \mathrm{C}$ and having a mean rainfall of $1534 \mathrm{~mm} /$ year. The identification of the plant material was done by Professor Mohamed Larbi Khouja and a voucher specimen (PPR2014 and PPM2014, for Renoui and Maghrebiana, respectively) of the plant was deposited at the Herbarium of INRGREF (Tunisia).

\section{Essential oil isolation and analysis}

Needles $(150 \mathrm{~g})$ were separately grounded and submitted to hydrodistillation for $3 \mathrm{~h}$ using a Clevenger-type apparatus. The distilled oils were dried over anhydrous sodium sulfate and stored in tightly closed dark vials at $4^{\circ} \mathrm{C}$ until analysis. The essential oil was analyzed as previously described. ${ }^{7}$ Identification of constituents was made as elsewhere reported. ${ }^{8}$ Component relative concentrations were calculated based on GC peak areas without using correction factors.

\section{Antioxidant activity evaluation}

To assess the antioxidant potential of bioactive compounds, the application of at least two different assays varying in their mechanisms of antioxidant action has been recommended. ${ }^{9}$ The antioxidant capacity of the studied samples was determined applying the DPPH and ABTS assays.

DPPH assay. The DPPH radical scavenging capacity was measured according to Boukhris et $a l .{ }^{10}$ with some modification. Each experiment was analyzed in triplicate.

ABTS assay. ABTS radical cation $\left(\mathrm{ABTS}^{+}\right)$ was produced by reacting ABTS stock solution with $2.45 \mathrm{mM}$ potassium persulfate and allowing the mixture to stand in the dark at room temperature for $16 \mathrm{~h}$ before use. ${ }^{11}$ The concentration of the test extract providing 50\% inhibition $\left(\mathrm{IC}_{50}\right.$, expressed in $\left.\mu \mathrm{g} \cdot \mathrm{mL}^{-1}\right)$ was calculated from the graph plotted with inhibition percentage against the extract concentration.

\section{Microbial strains}

The different essential oils of $P$. pinaster var. were tested for their antibacterial and antifungal activities against 10 indicators microorganisms including seven bacteria reference pathogenic (Escherichia coli ATCC 8739, Salmonella typhimurium NCTC 6017, Staphylococcus aureus ATCC 29213, Pseudomonas aeruginosa ATCC27853, Aeromonas hydrophila EI, Listeria monocytogenes ATCC 7644, and Bacillus cereus ATCC 1247), and three fungi species (Aspergillus flavus, Aspergillus niger and Candida albicans ATCC 2091). ${ }^{12}$

\section{Disk diffusion assay}

Antibacterial activity was evaluated using the method described by Choin et al. ${ }^{13}$ The discs were impregnated with essential oil diluted in hexane. A disc soaked in hexane was used as negative control. We used the bacterial strains for the culture medium Muller-Hinton. At the end of the incubation, 24 hours at $37^{\circ} \mathrm{C}$, the diameters of the zone of inhibition were measured.

\section{Statistical analysis}

All data were expressed as the average \pm standard deviation of the measurements. Quantitative differences was assessed by Tukey's test (at $p<0.05$ ) followed by Dunn's post-hoc multiple comparison test (SPSS. v15).

\section{RESULTS AND DISCUSSION}

\section{The Chemical composition of essential oils}

The yields extracted by hydrodistillation from the dried Needles were $0.02 \pm 0.004 \%$ and $0.26 \pm$ $0.03 \%$ for var. Renoui and var. Maghrebiana, respectively, which Marocco variety has the highest value. Pinus pinaster needles exhibited a 
low yield of the essential oils when compared with Aleppo pine needles growing in Algeria with a yield of $0.52 \%{ }^{14}$

The chemical composition of the essential oil of needles was investigated using GC-FID and GCMS apparatus. The chromatograms of $P$. pinaster of two varieties showed that the essential oils were a mixture of numerous compounds; some of them were present in trace amounts. One hundred and fifty components of the aromatic oil of var. Renoui were identified representing $95.91 \%$ of the total essential oil composition (Table 1). The major components of $P$. pinaster var. Renoui (Fig. 1) essential oil were trans-caryophyllene $(14.66 \%)$, abietane $(8.61 \%)$, $\Delta$-cadinene $(8.43 \%)$, sclarene $(8.25 \%)$ and trypethelone $(7.29 \%)$. Other important compounds were identified included 3-penten-2-one (4.8\%), germacrene D (4.63\%), $\alpha$-humulene $(4.45 \%)$, isovaleric acid (3.97\%), $\alpha$-cubebene $(3.4 \%)$, Vilgarol b (1.99\%), $\alpha$ - pinene $(1.99 \%)$, $\alpha$-bisabolene $(1.8 \%), \alpha$-amorphene $(1.39 \%)$ and $\beta$-cubebene (1.3\%). On the other hand, eighty-one components of the aromatic oil of var. Magrebiana were identified which $67.04 \%$ of the total essential oil composition. The major chemical constituents found in the essential oil from P.pinaster var. Maghrebiana needles are $\alpha$-amorphene $(10.72 \%)$, followed by trans-caryophyllene $(10.74 \%)$, $\beta$-cadinene $\quad(9.73 \%), \quad$ abietatriene $\quad(4.97 \%)$, $\alpha$-humulene $(3.53 \%)$, caryophyllene oxide (2.24\%), Germacrene D (1.86\%), phenethyl isovalerate $(1.71 \%), \alpha$-calacorene $(1.66 \%)$, guaiol (1.62\%), muurolol(1.52\%), $\alpha$-cadinol (1.44\%) and $\alpha$-cadinene $(0.99 \%)$.

Table 1

Chemical composition of essential oils of Pinus pinaster varieties

\begin{tabular}{|c|c|c|c|c|c|c|c|c|c|}
\hline $\mathbf{N}^{\circ}$ & Compounds & $\begin{array}{l}\text { P.pinaster } \\
\text { Var. } \\
\text { Maghrebiana } \\
(\%)\end{array}$ & $\begin{array}{l}P . \\
\text { pinaster } \\
\text { Var. } \\
\text { Renoui } \\
(\%)\end{array}$ & RI & $\mathbf{N}^{\circ}$ & Compounds & $\begin{array}{l}\text { P.pinaster Var. } \\
\text { Maghrebiana } \\
(\%)\end{array}$ & $\begin{array}{l}P . \text { pinaster } \\
\text { Var. Renoui } \\
(\%)\end{array}$ & RI \\
\hline 1 & Santene & - & 0.02 & 851 & 76 & $\beta$-bourbonene & 0.5 & - & 1594 \\
\hline 2 & $\alpha$-pinene & 0.21 & 1.99 & 931 & 77 & salvial-4(14)-en-1-one & - & 0.51 & 1596 \\
\hline 3 & $\Delta$ - limonene & - & 0.03 & 944 & 78 & guaiol & 1.62 & - & 1601 \\
\hline 4 & verbenene & - & 0.05 & 951 & 79 & $\alpha$-selinene & 0.18 & - & 1604 \\
\hline 5 & $\beta$-pinene & 0.02 & 0.22 & 972 & 80 & geranyl isovalerate & - & 0.27 & 1605 \\
\hline 6 & myrcene & 0.04 & - & 990 & 81 & $\begin{array}{l}\text { 3,4-dimethyl-3- } \\
\text { cyclohexene-1- } \\
\text { carboxaldehyde }\end{array}$ & 0.51 & - & 1610 \\
\hline 7 & isoterpinolene & 0.01 & - & 1014 & 82 & globulol & 0.45 & - & 1619 \\
\hline 8 & $\alpha$-terpinene & - & 0.83 & 1014 & 83 & Fonenol & - & 0.29 & 1620 \\
\hline 9 & o-cymene & 0.04 & 0.14 & 1022 & 84 & cadina-1,4-diene & 0.66 & - & 1628 \\
\hline 10 & $\beta$-phellandrene & 0.07 & 0.18 & 1026 & 85 & $\alpha$-elemene & 0.42 & - & 1632 \\
\hline 11 & $\begin{array}{l}\text { bicyclo[3.2.0]hept-6- } \\
\text { ene }\end{array}$ & 0.06 & - & 1067 & 86 & aromadendrene & - & 0.14 & 1634 \\
\hline 12 & $\alpha$-terpinolene & 0.25 & 0.55 & 1069 & 87 & T-muurolol & 1.52 & - & 1643 \\
\hline 13 & $o$-allyltoluene & - & 0.1 & 1087 & 88 & cedreanol & 0.46 & - & 1647 \\
\hline 14 & linalool & 0.08 & 0.06 & 1098 & 89 & $\beta$-eudesmol & 0.28 & - & 1652 \\
\hline 15 & $\alpha$-campholenal & 0.01 & 0.12 & 1123 & 90 & $\alpha$-cadinol & 1.44 & 0.62 & 1658 \\
\hline 16 & terpinene-1-ol & - & 0.02 & 1132 & 91 & calacorene & 0.47 & - & 1660 \\
\hline 17 & trans-pinocarveol & 0.02 & 0.11 & 1137 & 92 & 1-deoxycapsidiol & - & 0.11 & 1666 \\
\hline 18 & $\alpha$-phellandren-8-ol & - & 0.07 & 1146 & 93 & $\begin{array}{l}\text { caryophylla-3,8(13)- } \\
\text { dien-5.beta.-o }\end{array}$ & 0.52 & - & 1673 \\
\hline 19 & terpinene-4-ol & 0.03 & 0.12 & 1157 & 94 & $\gamma$-costol & - & 0.36 & 1673 \\
\hline 20 & pinocarvone & - & 0.04 & 1158 & 95 & $\alpha$-gurjunene & 0.21 & - & 1679 \\
\hline 21 & borneol & 0.03 & - & 1166 & 96 & Aristol-9-en-3-ol & - & 0.2 & 1686 \\
\hline 22 & $\begin{array}{l}\text { 2-methyl-cyclohexa- } \\
\text { 1,3-iene }\end{array}$ & - & 0.12 & 1166 & 97 & $\begin{array}{l}\text { Isoaromadendrene } \\
\text { epoxide }\end{array}$ & - & 0.04 & 1696 \\
\hline 23 & Cuminol & - & 0.04 & 1185 & 98 & $\begin{array}{l}9,10 \text {-dehydro- } \\
\text { isolongifolene }\end{array}$ & 0.07 & - & 1702 \\
\hline 24 & $\alpha$ - terpineol & 0.18 & 0.32 & 1189 & 99 & $\begin{array}{l}\text { 8,9-Dehydro- } \\
\text { Neoisolongifolene }\end{array}$ & - & 0.03 & 1704 \\
\hline 25 & trans-isolimonene & - & 0.19 & 1195 & 100 & $\begin{array}{l}\text { 1-methoxymethyl-2- } \\
\text { methylbenzene }\end{array}$ & 0.08 & - & 1709 \\
\hline 26 & $\begin{array}{l}\text { cyclohexene, 5- } \\
\text { methyl-3-(1- } \\
\text { methylethenyl)-, trans- }\end{array}$ & 0.06 & - & 1196 & 101 & Isospathulenol & - & 0.03 & 1714 \\
\hline 27 & homomyrtenol & - & 0.04 & 1203 & 102 & Farnesol & 0.73 & - & 1719 \\
\hline 28 & verbenone & - & 0.07 & 1206 & 103 & Farnesyl alcohol & - & 0.17 & 1719 \\
\hline 29 & $\begin{array}{l}\text { 3-cyclohexene-1- } \\
\text { cetaldehyde, } \alpha, 4- \\
\text { dimethyl- }\end{array}$ & - & 0.06 & 1212 & 104 & $\begin{array}{l}\text { isoaromadendrene } \\
\text { epoxide }\end{array}$ & 0.11 & 0.04 & 1727 \\
\hline 30 & $\Delta$-5,8-iridadiene & - & 0.12 & 1217 & 105 & $\begin{array}{l}\text { caryophylla-2(12),6- } \\
\text { dien-5-one }\end{array}$ & 0.07 & 0.02 & 1734 \\
\hline
\end{tabular}


Table 1 (continued)

\begin{tabular}{|c|c|c|c|c|c|c|c|c|c|}
\hline 31 & cis-geraniol & - & 0.03 & 1228 & 106 & farnesal & 0.12 & - & 1737 \\
\hline 32 & $\begin{array}{l}\text { cis-3-hexenyl } \\
\text { isovalerate }\end{array}$ & 0.05 & - & 1230 & 107 & $\begin{array}{l}\text { Alloaromadendrene } \\
\text { oxide }\end{array}$ & - & 0.05 & 1742 \\
\hline 33 & cis-3-hexenyl valerate & - & 0.21 & 1232 & 108 & Calamenene & - & 0.1 & 1758 \\
\hline 34 & hexyl isovalerate & 0.02 & - & 1238 & 109 & diepicedrene-1-oxide & 0.06 & - & 1767 \\
\hline 35 & piperitone & 0.01 & 0.03 & 1252 & 110 & 4-methyl-1,3-pentadiene & 0.04 & - & 1770 \\
\hline 36 & geraniol & - & 0.08 & 1255 & 111 & $\begin{array}{l}\text { 5-Heptenal, 2,6- } \\
\text { dimethyl- }\end{array}$ & - & 0.04 & 1770 \\
\hline 37 & nerol & 0.03 & - & 1258 & 112 & valencen & 0.05 & - & 1773 \\
\hline 38 & 1-bornyl acetate & 0.07 & - & 1281 & 113 & $\begin{array}{l}\text { Isoaromadendrene } \\
\text { Epoxide }\end{array}$ & - & 0.02 & 1775 \\
\hline 39 & 1-bornyl acetate & - & 0.05 & 1281 & 114 & dehydroaromadendrene & - & 0.25 & 1788 \\
\hline 40 & $\begin{array}{l}\text { eudesma-4(14),11- } \\
\text { diene }\end{array}$ & 0.15 & - & 1325 & 115 & $\begin{array}{l}\text { 15,16-dinorlabd- } 8(20) \text { - } \\
\text { en-13-one }\end{array}$ & - & 0.02 & 1793 \\
\hline 41 & 1,3-p-menthadiene & 0.08 & - & 1330 & 116 & methandrostenolone & - & 0.08 & 1825 \\
\hline 42 & $\Delta$-1,8-iridadiene & - & 0.07 & 1332 & & lepidozenal & - & 0.04 & 1797 \\
\hline 43 & aromadendrene & 0.17 & - & 1333 & 117 & neophytadiene & 0.1 & 0.07 & 1831 \\
\hline 44 & germacrene B & - & 0.11 & 1333 & 118 & farnesyl acetate 3 & 0.43 & 0.06 & 1835 \\
\hline 45 & cyclosativene & - & 0.02 & 1362 & 119 & $\beta$-costol & - & 0.29 & 1859 \\
\hline 46 & $\alpha$-ylangene & 0.33 & 0.66 & 1366 & 120 & trans-phytol & 0.04 & & 1873 \\
\hline 47 & $\alpha$-cubebene & 2.23 & 3.4 & 1375 & 121 & Benzalpinacolone & - & 0.04 & 1879 \\
\hline 48 & $\alpha$-copaene & 0.09 & 0.36 & 1383 & 122 & isopimara-7,15-diene & 0.05 & & 1896 \\
\hline 49 & longifolene & - & 0.3 & 1401 & 123 & $\begin{array}{l}\text { 1(2H)-Naphthalenone, } \\
\text { 3,4-dihydro-3,3,6,8- } \\
\text { tetramethyl- }\end{array}$ & - & 0.06 & 1897 \\
\hline 50 & junipen & 0.65 & - & 1402 & 124 & Biformene & - & 0.01 & 1907 \\
\hline 51 & trans-caryophyllene & 10.74 & 14.66 & 1432 & 125 & geranyl linalool isomer & 0.03 & & 1911 \\
\hline 52 & $\beta$-cubebene & 0.64 & 1.3 & 1434 & 126 & geranyl linalool & - & 0.02 & 1912 \\
\hline 53 & $\alpha$-guaiene & 0.05 & - & 1438 & 127 & $\alpha$-Cedrenal & - & 0.02 & 1917 \\
\hline 54 & isoledene & 0.24 & - & 1443 & 128 & pimara-8(9),15-diene & - & 0.58 & 1929 \\
\hline 55 & $\alpha$-humulene & 3.53 & 4.45 & 1459 & 129 & manool & 0.01 & & 1940 \\
\hline 56 & $\gamma$-gurjunene & - & 0.11 & 1469 & 130 & $\begin{array}{l}\text { ent-pimara-8(14),15- } \\
\text { diene }\end{array}$ & - & 0.03 & 1941 \\
\hline 57 & $\alpha$-amorphene & 10.72 & 1.39 & 1484 & 131 & $\gamma$-patchoulene & - & 0.12 & 1948 \\
\hline 58 & Germacrene D & 1.86 & 4.63 & 1488 & 132 & $\alpha$-bisabolene & - & 0.19 & 1969 \\
\hline 59 & unkown & - & 3.03 & 1493 & 133 & cembrene & 0.02 & - & 1983 \\
\hline 60 & phenethyl isovalerate & 1.71 & - & 1495 & 134 & epimanoyl oxide & 0.17 & 0.29 & 1988 \\
\hline 61 & isovaleric acid & - & 3.97 & 1500 & 135 & sclaren & - & 8.25 & 2033 \\
\hline 62 & $\beta$-cadinene & 9.73 & - & 1509 & 136 & $\begin{array}{l}\text { alternariol monomethyl } \\
\text { ether }\end{array}$ & - & 1 & 2036 \\
\hline 63 & $\Delta$-cadinene & - & 8.43 & 1534 & 137 & Pumiloxide & - & 0.12 & 2049 \\
\hline 64 & $\alpha$-cedrene & 0.38 & - & 1538 & 138 & abietatriene & 4.97 & - & 2065 \\
\hline 65 & cadine-1,4-diene & - & 0.3 & 1538 & 139 & abietane & - & 8.61 & 2077 \\
\hline 66 & $\alpha$-cadinene & 0.99 & - & 1541 & 140 & trypethelone & - & 7.29 & 2107 \\
\hline \multirow[t]{2}{*}{67} & $\alpha$-bisabolene & - & 1.8 & 1547 & 141 & 3-penten-2-one & - & 4.8 & 2127 \\
\hline & $\begin{array}{l}1- \\
\text { methyl[2.2]paracyclop } \\
\text { han-1-en }\end{array}$ & 0.13 & - & 1552 & 142 & $\begin{array}{l}\text { androst-5-ene, 4,4- } \\
\text { dimethyl-, (13.alpha.)- }\end{array}$ & 0.16 & - & 2235 \\
\hline 68 & myrtenal & - & 0.32 & 1556 & 143 & 5. $\beta$-pregn-11-ene & - & 0.38 & 2237 \\
\hline 69 & $\alpha$-calacorene & 1.66 & - & 1565 & 144 & $\begin{array}{l}\text { (12S)-15-16-Epidioxy- } \\
\text { 13-labdene-8,12-diol }\end{array}$ & - & 0.22 & 2253 \\
\hline 70 & 3-hexenyl benzoate & - & 0.22 & 1573 & 145 & $\begin{array}{l}\text { 7-oxoabieta- } 8,11,13 \text { - } \\
\text { triene }\end{array}$ & 0.22 & - & 2296 \\
\hline 71 & $\beta$-selinene & 0.16 & 0.32 & 1576 & 146 & $\begin{array}{l}\text { abieta-8,11,13-trien-7- } \\
\text { one }\end{array}$ & - & 0.21 & 2297 \\
\hline 72 & camphene & - & 0.47 & 1578 & 147 & $\begin{array}{l}\text { 7-isopropyl-4-[2'-(4'- } \\
\text { ethoxyphenyl)ethenyl]- } \\
\text { 1-methylazulene }\end{array}$ & 0.09 & - & 2302 \\
\hline 73 & phenylethyl tiglate & - & 0.19 & 1582 & 148 & $\begin{array}{l}\text { trans-trismethoxy } \\
\text { Resveratrol }\end{array}$ & - & 0.15 & 2308 \\
\hline 74 & caryophyllene oxide & 2.24 & 0.09 & 1587 & 149 & ferruginol & - & 0.08 & 2327 \\
\hline \multirow[t]{3}{*}{75} & vilgarol b & - & 1.99 & 1589 & 150 & calyculone & 0.15 & - & 2334 \\
\hline & & & & & 151 & dehydroabietic acid & - & 0.2 & 2338 \\
\hline & & & & & 152 & methyl abietate & 0.04 & 0.03 & 2381 \\
\hline
\end{tabular}

Notes: RI: retention indices calculated in regard to standards mixture of hydrocarbons $\left(\mathrm{C}_{8}-\mathrm{C}_{28}\right)$ for $4.790-48.969$ min. \%: Percentage calculated by GC-FID on HP-INNOWax. RI: retention index. 


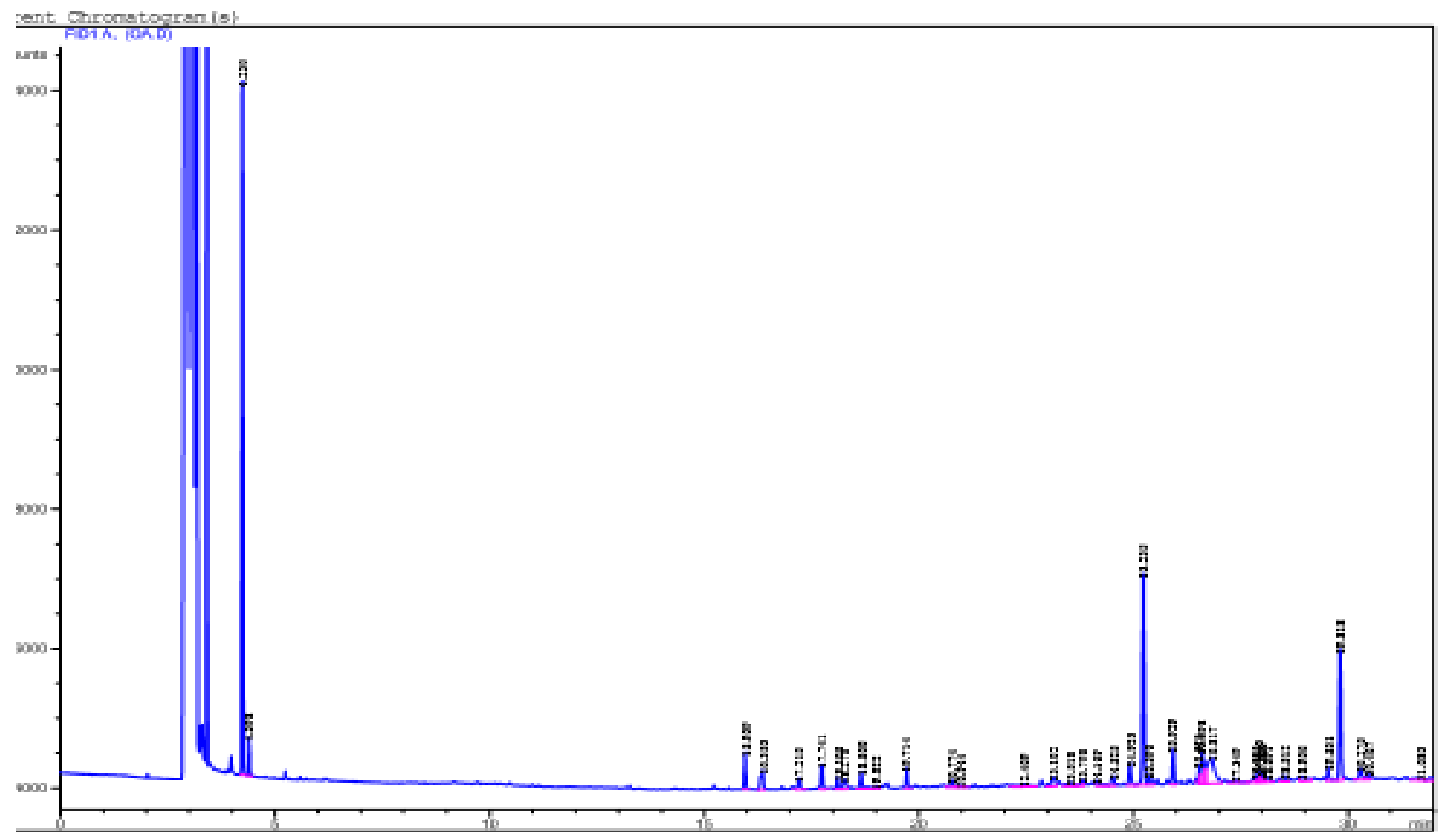

Fig. 1 - GC-FID chromatograms of essential oil of Pinus pinaster var. Renoui.

Volatile organic materials for two varieties are consisting of complex mixtures of mono-, sesqui-, dihydrocarbons, and oxygenated materials biogenically derived from them. According to the literature, monoterpenes and sequitepenes are the components found to occur in higher quantities in essential oils from Pinus species ${ }^{15}$ and trans-caryophyllene was identified as the major component in the essential oils of $P$. pinaster. These results were in accordance with previous studies in essential oil collected from north Africa ${ }^{16,17}$ while, the needle essential oils of $P$. pinaster from Russia (99.8\%), Portugal (97.5\%), Argentina (83.2\%), Italy (28.9\% and $21.7 \%)$ and France (44.1\% and $29.5 \%$ ). It is worth noting that the essential oil of $P$. pinaster endemic of Morocco were rich in germacrene D (62.5\%) and $\beta$-caryophyllene $(22.2 \%) .{ }^{18}$ These results were not in accordance with those reported by our research team who found that germacrene D were present only at $1.86 \%$ and 4.63 in $P$. pinaster var. Maghrébiana and $P$. pinaster var. Renoui, respectively. On the other hand, Amri et al. ${ }^{19}$ mentioned that $P$. pinaster oil collected from the National Research Institute of Rural Engineering, Water, and Forests (INRGREF) arboretum (Northeast of Tunisia), was characterized by the high level of $\alpha$-pinene (31.4\%) followed by transcaryophyllene (28\%), and $\alpha$-humulene $(6.7 \%)$. It is well established that a literature survey showed many differences in the composition of $P$. pinaster essential oil. These variances could be because of the difference between ecotypes, and other environmental parameters.

Moreover, Macchioni et al. ${ }^{20}$ showed that the major compounds of the $P$. pinaster essential oils of all the three plant parts (needles, branches and cones) were the pinenes, with total percentages more than $50 \%$. In addition, longifolene was also found in important amounts in the essential oils of the branches and the female cones $(7.7 \%$ and $20.8 \%$, respectively) and decreased to $1.1 \%$ in the essential oil of the needles. As previously shown ${ }^{21}$, the main components of the essential oil of $P$. pinaster needles were $\alpha$-pinene, $\beta$-pinene, caryophyllene and germacrene $\mathrm{D}$. On the other hand, others studies $^{22,23}$ reported high amounts of longifolene, followed by $\alpha$-pinene. It was noted that the composition of the essential oil varies with climate, season location, soil type, age of plants and leaves, and the method used for drying and extraction.

\section{Determination of Antioxidant activity}

The results of the antioxidant activities were determined by two tests namely: DPPH radical scavenging and ABTS radical cation. The two essential oil samples showed antioxidant activity, but 
significantly, statistic differences were only observed when they were compared by two varieties. As it was shown in Table 2, Renoui variety oil showed the highest antioxidant activity $\left(\mathrm{IC}_{50}=42 \pm 1.31 \mu \mathrm{g} \cdot \mathrm{mL}^{-1}\right)$ when compared to Magrebiana variety $\left(\mathrm{IC}_{50}=56 \pm\right.$ $1.04 \mu \mathrm{g} . \mathrm{mL}^{-1}$ ). ABTS test confirm result obtained by DPPH one which Magrebiana Variety exhibited the lowest level $65 \pm 1.2 \mu \mathrm{g} \cdot \mathrm{mL}^{-1}$. Antioxidant activities of essential oils from medicinal plants are mainly attributed to the active compounds. ${ }^{24}$ This can be due to the high percentage of main constituents, but also to the presence of other constituents in small quantities or to synergy among them. ${ }^{25}$ In this study, the antioxidant activities were related to the contents of essential oils of Pinus pinaster var. Renoui: transcaryophyllene $(14.66 \%)$, abietane $(8.61 \%)$, $\Delta$-cadinene $(8.43 \%), \quad$ sclaren $(8.25 \%)$ and trypethelone $(7.29 \%)$ and to the presence in high amount of $\alpha$-amorphene $(10.72 \%)$, transcaryophyllene $(10.74 \%), \beta$-cadinene $(9.73 \%)$ for Pinus pinaster var. Magrebiana essential oil. The difference of antioxidant essential oil between two $P$. pinaster varieties may be related to the genotype and geographic origin. The antioxidant activity may be due to different mechanisms, such as prevention of chain initiation, decomposition of peroxides, and prevention of continued hydrogen abstraction, free radical scavenging, reducing capacity, and binding of transition metal ion catalysts. ${ }^{26}$ It is thus important that for evaluating the effectiveness of antioxidants, several analytical methods. Our results are in agreement with it was reported by Yongjun et al. ${ }^{27}$ which showed an important in vitro antioxidant activity of the essential oils of Pinus armandii cones. $^{28}$

\section{Determination of Antimicrobial activity}

Table 3 summarized the qualitative (diameters of inhibition zones) of the in vitro antimicrobial effect of the essential oil of Pinus pinaster varieties on the ten microbial strains. The diameters of inhibitory zones recorded in millimeter. It was observed that the oil was efficient against some tested microbial strains. The size of all inhibition zones was between 6 to $20 \mathrm{~mm}$. Our results showed an antibacterial activity against $S$. aureus. and $B$. cereus of essential oil of two $P$. pinaster varieties. The same result is found $^{16}$ in the essential oil of $P$. pinaster from Algeria. Thus Gram-positive found a sensibility against the essential oil of $P$. pinaster while the Gram-negative strains of bacteria were more resistant as it was reported by Lambertn et al. ${ }^{29}$ and Wilkinson et al. ${ }^{30}$

The essential oils of Pinus pinaster did not inhibit the growth Candida Albicans, Aspergillus flavous and Aspergillus niger. Antimicrobial activity of essential oils might be attributed to variation in chemical compounds. In the same context, our result mentioned that antifungal activity of Pinus essential oil can be attributed to the higher amount of $\alpha$-pinene, as well the oil from Pistacia lentiscus. ${ }^{31}$

\section{CONCLUSION}

Our finding revealed significant variations in the yields, chemical content and antioxidant activity of essential oils between $P$. pinaster varieties endemic of North Africa growing in North West of Tunisia. No significant antimicrobial potentials difference was found between the two studied samples. The difference of chemical composition and biological activities of the two $P$. pinaster varieties may be related to the genotype and geographic origin. Finally, this study suggests that $P$. pinaster needles essential oil of North African area will be a good resource as natural antioxidant and an antibacterial agent.

\footnotetext{
Acknowledgements. This research was financially supported by the Hight Ministry of education and scientific research as well as National Research Institute of Rural Engineering, Water and Forestry of Tunisia.
}

Table 2

Antioxidant activities of Pinus pinaster varieties essential oils

\begin{tabular}{lcc}
\hline & DPPH $\left(\boldsymbol{\mu g} . \mathbf{m L}^{-1}\right)$ & ABTS $\left(\boldsymbol{\mu g} . \mathbf{m L}^{-1}\right)$ \\
\hline Pinus pinaster var Magrebiana & $\mathbf{5 6} \pm \mathbf{1 . 0 4}{ }^{\mathrm{a}}$ & $\mathbf{6 5} \pm \mathbf{1 . 2}$ \\
Pinus pinaster var Renoui & $\mathbf{4 2} \pm \mathbf{1 . 3 1}^{\mathrm{b}}$ & $\mathbf{5 2} \pm \mathbf{1 . 4 5}^{! !}$ \\
\hline
\end{tabular}

Results are expressed as mean \pm standard deviation of 3 determinations. Means with different symbols and letters were significantly different at $p<0.05$. 
Table 3

Antimicrobial activity of $P$. pinaster essential oils (growth inhibition zones in $\mathrm{mm}$ )

\begin{tabular}{clcc}
\hline & & \multicolumn{2}{c}{ ID (mm) } \\
& & $\begin{array}{c}\text { Pinus pinaster } \\
\text { var. Magrebiana }\end{array}$ & $\begin{array}{c}\text { Pinus pinaster } \\
\text { var. Renoui }\end{array}$ \\
\hline Gram-negative & E. coli & 8 & 10 \\
Bacteria & S. typhimurium & 7 & 8 \\
& A. hydrophila & 6 & 5 \\
Gram-positive & P. aeruginosa & 9 & 7 \\
Bacteria & L. aureus & 18 & 20 \\
& B. cenocystogenes & 6 & 8 \\
Fungus & Asp. Flavus & 10 & 13 \\
& Asp. niger & - & - \\
& C. albicans & - & - \\
\hline
\end{tabular}

Note: No activity found.

\section{REFERENCES}

1. R. A. Mothana, M. S. Alsaidn, S. S. Hasoon, N. M. AlMosaiyb, A. J Al-Rehaily and M. A. Al-Yahya, J. Med. Plants. Res., 2012, 6, 3066.

2. P. Schauenberg and F. Paris, Neuchatel., 1977, 386.

3. S. Iravani and B. Zolfaghari, Res. Pharm. Sci., 2011, 6, 1.

4. J. S.Carrión, C. Navarro, J. Navarro and M. Munuera, Holocene., 2000, 10, 243.

5. DGF, General Directorate of Forestry. Results of the first national forest inventory Tunisia. Ministry of Agriculture., $1995,87$.

6. B. Belghazi and M. Ezzahiri, Ann. For. Sci. (Rabat)., $1995,28,17$.

7. M. Boukhris, M. Bouaziz, I. Feki, H. Jemai, A. El Feki and S. Sayadi, Lip. Heal. Dis., 2012, 11, 81.

8. J. Valente, M. Zuzarte, R. Resende, M. J. Goncalves, C. Cavaleiro, C. F. Pereira, M. T. Cruz and L. Salgueiro, Ind. Crop. Prod., 2015, 65, 361.

9. G. Rigane, R. Ben Salem, S. Sayadi and M. Bouaziz, J. Food. Sci., 2011, 76, 965.

10. G. Rigane, S. Ben Younes, H. Ghazghazi and R. Ben Salem, Int. Food. Res. J., 2013, 20, 3001.

11. N. R. Re, Pellegrini, A. Proteggente, A. Pannala, M. Yang and C. A. Rice-Evans, F. Ra. Biol. Med., 1999, 26, 1231.

12. C. Trakhna, A. Harf-Monteil, A. Abdel-Nour, Maaroufin and P. Gadonna-Widehem, Lett. Appl. Microbiol., 2009, 49, 186.

13. Y. M. Choin, D. O. Noh, S. Y. Cho, H. J. Suh and J. M. Kim, Food. Sci. Tech., 2006, 39, 756.

14. I. Touihri, M. Boukhris, N. Marrakchi, J. Louisn, B. Hanchi and O. Kallech-Ziri, J. Olea. Sci., 2015, 64, 869.

15. I. Zafar, A. Fatima, S. J. Khan, Z. Rehman and S. Mehmud, Pak. J. Biochem. Mol. Biol., 2011, 44, 36.
16. A. T. Nouara, A. M. Djouher and Y. Aziza, J. Coast. Life. Med., 2013, 1, 54 .

17. T. Dob, T. Berramdane and C. Chelghoum, Chem. Nat. Compd., 2005, 4, 545.

18. M. Hmamouchi, J. Hamamouchi, M. Zouhdi and J. M. Bessière, J. Essent. Oil. Res., 2001, 13, 298.

19. I. Amri, M. Hanana, S. Gargouri, B. Jamoussi and L. Hamrouni, Chil. J. Agr. Res., 2013, 73.

20. F. Macchioni, P. L. Cioni, G. Flamini, G. I. Morelli, S. Maccioni and M. Ansaldi, Fla. Frag., 2003, 18, 139.

21. P. V. Petrakis, C. Tsitsimpikou and O. Tzakou, Flav. Fra. $J, 2001,16,249$.

22. M. Valero and E. Frances, Food. Microbiol, 2006, 23, 68.

23. D. R. Batish, H. P. Singh, R. K. Kohli and S. Kaur, For. Ecol. Manag, 2008, 256, 2166.

24. S. Burt, Food. Microbial., 2004, 94, 223.

25. S. Y. Wang, C. T. Chen, W. Sciarappa, C. Y. Wang and M. J. Camp, Agric. Food. Chem., 2008, 56, 5788.

26. L. C. Mao, X. Pan, F. Que and X. H. Fang, Europ. Food. Res. Tech., 2006, 222, 236.

27. T. Yongjun, H. Kidokoro, T. Watanabe, Y. Igeta, H. Sakaji and S. Ino, J. Mar. Sys., 2012, 19, 1.

28. X. Yang, H. T. Zhao, J. Wang, Q. Meng, H. Zhang, L. Yao, Y. C. Zhang, A. J. Dong, Y. Man, Z. Wang, D. C. Xu and Y. Ding, J. Med. Plants. Res., 2010, 4, 1668.

29. R. L. Lambertn, P. N. Skandamis, P. J. Coote and G. J. Nychas, K. G. Lee, Shibamoto., 1983, 74, 443.

30. J. M. Wilkinson, M. Hipell, T. Ryan and H. M.Cavanagh, Agric. Food. Chim, 2003, 51, 76.

31. M. Krauze-Baranowsk, M. Mardarowicz, M. Wiwart, L. Poblocka and M. Dynowska, Z Naturforsh C., 2002, 57,478 . 
